\title{
A typology of leadership style: Examining gender and race effects
}

\author{
VERONICA G. THOMAS and LAWRENCE W. LITTIG \\ Howard University, Washington, DC
}

\begin{abstract}
A fourfold typology of leadership style was assessed using the Leadership Opinion Questionnaire. Two hundred and fifty male and 280 female business administration and management students participated in this research. A significant relationship emerged between race and leadership typology. Gender was not significantly related to leadership typology. The significance of these findings and implications for leadership potential are discussed.
\end{abstract}

The behavior of individuals in positions of leadership has long been an important and ongoing focus of social psychological research (e.g., Cowley, 1928; Fleishman \& Hunt, 1973; Hemphill, 1949; Hunt \& Jordan, 1939). Leadership research through the early 1970s, however, dealt primarily with white male subjects. As a result, the theories put forth were based on results that excluded women and minorities. During the last decade, an increasing number of empirical studies have examined sex effects in leadership behavior (e.g., Bartol, 1973; Eskilson \& Wiley, 1976; Lord, Phillips, \& Rush, 1980). Concurrently, a much smaller program of research on minority leaders has emerged (Parker, 1976; Richards \& Jaffee, 1972).

With a conscious effort in many organizations to increase the numbers of women and minorities in positions of authority, the leadership potential of these individuals has taken on real significance. However, research that has emerged within the last decade on race and gender effects in leadership behavior is ambiguous. For instance, whereas some research has supported the proposition that blacks and whites have similar behavioral patterns in leadership situations (Hill \& Fox, 1973; Hill \& Ruhe, 1974), other research has suggested differential behavior (Allen, 1975; Richards \& Jaffee, 1972; Ruhe, 1973). Similarly, some studies have indicated sex differences in leadership style (Bartol, 1973; Eskilson \& Wiley, 1976; Martin, 1972), whereas others have yielded few or no differences (Arnett, Higgins, \& Priem, 1980; Bedeian, Armenakis, \& Kemp, 1976; Chapman, 1975; Stitt, Schmidt, \& Price, 1983; Wexley \& Hunt, 1974). Lengthy reviews of sex differences in leadership research, however, have been more consistent with the latter findings (Bartol, 1978), whereas no major consensus has emerged regarding racial differences and similarities in leadership behavior.

A deficiency of much of this previous research is the failure to assess a typology of leadership behavior. In this

Requests for reprints should be sent to V. G. Thomas, Institute for Urban Affairs and Research, Howard University, 2900 Van Ness Street, N.W., Washington, DC 20008. sense, typology refers to a classification schema that simultaneously comprises two or more leadership styles. The absence of a typology can lead to descriptions of leadership style that do not differentiate behavior sufficiently, and thus mask important similarities or differences between various types of leaders. The utility of devising a typology of leadership becomes even more evident when it is recognized that the behavior of individuals who are typed as high on one leadership dimension may vary considerably depending upon whether they are simultaneously classified as low or high on other dimensions of leadership. Although leader behavior is theorized as consisting of independent dimensions (Fleishman \& Harris, 1962), only a small proportion of studies has presented leadership style in a typological manner (e.g., Fleishman \& Harris, 1962; Inderlied \& Powell, 1979; Weed, Mitchell, \& Moffitt, 1976). The purpose of this research was to examine further a typology of leadership behavior. In addition, race and sex effects were explored within this framework.

\section{METHOD}

\section{Subjects}

Two hundred and fifty (121 white; 129 black) male and 280 (101 white; 179 black) female business administration and management students participated in this investigation. All participants were either juniors or seniors.

\section{Instruments}

The Leadership Opinion Questionnaire (Fleishman, 1969) was used to assess leadership style. The questionnaire measures two basic dimensions of leadership: (1) consideration, which reflects the extent to which an individual is likely to have job relationships characterized by mutual trust, respect for subordinates' ideas, consideration for their feelings, and a lot of socioemotional support; and (2) initiation of structure, which reflects the extent to which an individual provides direction and is likely to define and structure his (her) role and those of subordinates toward goal attainment. Scores from the items are summed to provide a total consideration and initiation-of-structure score.

Utilizing scores from the questionnaire, a fourfold typology of leadership behavior was constructed. The subjects were placed in one of four leadership typologies on the basis of whether they had scored above or below the median on both scales or above the median on one scale and below the median on the other scale. The results of this classification scheme yielded four leadership typologies, each representing a different mix of consideration and structure orientation as follows: (1) high 
consideration and low structure (HC/LS), or a lot of socioemotional support and not much direction to subordinates; (2) high consideration and high structure (HC/HS), or a lot of socioemotional support and a lot of direction to subordinates; (3) low consideration and low structure (LC/LS), or not much socioemotional support and not much direction to subordinates; and (4) low consideration and high structure (LC/HS), or not much socioemotional support and a lot of direction to subordinates.

\section{Procedure}

The subjects were tested in groups of 15 to 25 . After being seated, the participants were given the questionnaire and the following instructions:

On the following pages, you are given a set of 40 behaviors that supervisors typically may engage in. Imagining that you are a supervisor, choose the alternative which most nearly expresses your opinion on how frequently you think you would do what is described by that item.

The procedure took approximately 15 to $20 \mathrm{~min}$ to complete.

\section{RESULTS}

The mean score for the consideration subscale for the sample in this investigation was 53.3, and the mean for the initiation-of-structure subscale was 53.2. These data are similar to those reported by Fleishman (1969) for various groups (i.e., industrial foreman, means $=54.4$ for consideration and 50.6 for initiation of structure; executives, means $=\mathbf{5 5 . 3}$ for consideration and 50.6 for initiation of structure; management training students, means $=53.6$ for consideration and $\mathbf{4 4 . 3}$ for initiation of structure; office supervisors, means $=53.2$ for consideration and 52.4 for initiation of structure).

A chi-square test of significance on subjects' race by leadership typology yielded significant results $\left[\chi^{2}(3)=\right.$ $66.2, \mathrm{p}<.001 ; \mathrm{N}=530]$. As indicated in Table $1,38 \%$ of the black subjects were classified as $\mathrm{HC} / \mathrm{HS}$, whereas only $14 \%$ of the whites were classified as HC/HS. However, the whites were more likely to be lower on both leadership dimensions than the blacks. That is, $32 \%$ of the white subjects were LC/LS types, whereas only $16 \%$ of the blacks were in this typology. Of HC/LS leadership styles, $34 \%$ of the white subjects were in this group, whereas only $15 \%$ of the blacks fell within this typology. It is interesting to note that blacks comprised $79 \%$ of the individuals classified as $\mathrm{HC} / \mathrm{HS}$ types, whereas whites comprised the remaining $14 \%$. Yet whites $(59 \%)$ constituted a larger percentage of LC/LS types than blacks (41\%).

The four typologies of leadership behavior were ex-

Table 1

Race and Leadership Typology

\begin{tabular}{|c|c|c|c|c|c|c|}
\hline \multirow{3}{*}{$\begin{array}{c}\text { Leadership } \\
\text { Typology }\end{array}$} & \multicolumn{6}{|c|}{ Race of Subject } \\
\hline & \multicolumn{2}{|c|}{ White } & \multicolumn{2}{|c|}{ Black } & \multicolumn{2}{|c|}{ Total } \\
\hline & $\mathrm{N}$ & $\%$ & $\mathbf{N}$ & $\%$ & $\mathbf{N}$ & $\%$ \\
\hline $\mathrm{HC} / \mathrm{LS}$ & 75 & 34 & 46 & 15 & 121 & 23 \\
\hline $\mathrm{HC} / \mathrm{HS}$ & 31 & 14 & 117 & 38 & 148 & 28 \\
\hline LC/LS & 71 & 32 & 50 & 16 & 121 & 23 \\
\hline LC/HS & 45 & 20 & 95 & 31 & 140 & 26 \\
\hline Total & 222 & 100 & 308 & 100 & 530 & 100 \\
\hline
\end{tabular}

$\chi^{2}(3)=66.2, p<.001 ; N=530$. amined in relation to gender of the subject. The chi-square analysis did not indicate a significant relationship. In addition, no significant relations emerged when gender and race were examined simultaneously.

\section{DISCUSSION}

The present study extends the use of a fourfold typology of leadership behavior. Although theory suggests that the dimensions of consideration and initiation of structure are independent, many researchers present their results as though these dimensions are bipolar and mutually exclusive. The use of a classification scheme, such as the one described in this research, increases precision in description of leadership behavior.

This research also examined gender and race effects in leadership typology. Results of the investigation did not indicate a significant relationship between gender and the four types of leadership style. Consequently, gender differences in leadership behavior may not be as evident as sex stereotyping, documented as one of the biggest barriers to the integration of women into leadership positions (Brown, 1979; Terborg, 1977), would lead us to believe. The similarities in leadership typology of the male and female management students in this research illustrate the danger of common global stereotypes regarding the leadership potential, or lack thereof, of women. This especially could be the case for a sample of men and women matched in terms of their educational training in business management. Foster and Kolinko (1979) noted that women preparing for careers in management appear to be a "special breed" when contrasted with their more traditional counterparts and that they evidence little or no fear of "sex-role inappropriateness."

Race was significantly related to leadership typology. Although blacks and whites had equal potential to utilize an array of consideration- and structure-oriented behaviors, blacks tended to make use of a substantially greater amount of both of these behaviors than whites. This is evident from the higher concentration of blacks, both men and women, in the $\mathrm{HC} / \mathrm{HS}$ typology. It may be that, due to the heightened visibility that blacks in leadership roles anticipate, such individuals are compelled to achieve and produce (i.e., through their structuring and directive behaviors), and yet at the same time they have the desire not to be viewed as punitive or as lacking sensitivity toward their subordinates (i.e., through their socioemotional or considerate behaviors). The white students in this study were more likely to utilize one dominant style, considerate-type behaviors, in their leadership orientation. They were also more likely than blacks not to utilize any of the consideration- or structure-oriented behaviors, as indicated by their distribution in the LC/LS typology. Overall, these findings suggest that blacks may generally be more active than whites in their leadership roles.

Generalization of the present results may be limited by the fact that the research participants were undergraduate students rather than actual supervisors. Sashkin and Garland (1979), however, pointed out that undergraduates may be more heterogeneous with respect to characteristics associated with leadership than would be a group of "real" supervisors chosen from within one company or industry, which is the kind of sample most often used in field studies. Considering that large numbers of college students, particularly those in business schools, will one day occupy supervisory positions in a wide variety of organizations, there may be sufficient justification for generalizing from this population to "supervisors in general" than from a sample of supervisors studied within one "real organization."

\section{REFERENCES}

ALLEN, W. R. (1975). A comparative analysis of black and white leaders in a naturalistic setting. Unpublished doctoral dissertation, University of Florida, Gainesville.

Arnett, M. D., Higgins, R. B., \& Priem, A. P. (1980). Sex and leastpreferred co-worker score effects in leadership behavior. Sex Roles, 6, 139-152.

BARTOL, K. M. (1973). Male and female leaders of small groups. East Lansing: Michigan State University, Bureau of Economic and Business Research. 
BARTOL, K. M. (1978). The sex structuring of organizations: A search for possible causes. Academy of Management Review, 3, 805-815.

Bedeian, A. G., ArmenaKis, A. A., \& Kemp, B. W. (1976). Relation of sex to perceived legitimacy of organizational influence. Journal of Personality, 94, 93-99.

BRown, S. M. (1979). Male versus female leadership: A comparison of empirical studies. Sex Roles, 5, 595-611.

Chapman, J. B. (1975). Comparison of male and female leadership style. Academy of Management Journal, 18, 645-650.

CowlEY, W. H. (1928). Three distinctions in the study of leaders. Journal of Abnormal and Social Psychology, 23, 144-157.

EsKILSON, A., \& WiLEY, M. (1976). Sex composition and leadership in small groups. Sociometry, 39, 183-194.

Fleishman, E. A. (1969). Manual for Leadership Opinion Questionnaire. Chicago, IL: Science Research Associates.

Fleishman, E. A., \& Harris, E. F. (1962). Patterns of leadership behavior related to employee grievances and turnover. Personnel Psychology, 15, 43-56.

Fleishman, E. A., \& Hunt, J. G. (1973). Current developments in the study of leadership. Carbondale, IL: Southern Illinois University Press.

Foster, L. W., \& Kolinko, T. (1979). Choosing to be a managerial woman: An examination of individual variables and career choice. Sex Roles, 5, 627-633.

HEMPHILL, J. K. (1949). Situational factors in leadership (Monograph No. 32). Columbus, OH: The Ohio State University, Bureau of Educational Research.

HILl, W. A., \& Fox, W. M. (1973). Black and white Marine squad leaders' perceptions of racial mixed equals. Academy of Management Journal, 16, 680-686.

Hill, W. A., \& RUhe, J. A. (1974). Attitudes and behaviors of black and white supervisors in problem solving groups. Academy of Management Journal, 17, 563-569.

HUNT, J. E., \& JoRDAN, A. M. (1939). An analysis of qualities associated with leadership among college students. Journal of Educational Psychology, 39, 497-509.
INDERLied, S. D., \& Powell, G. (1979). Sex role identity and leadership style: Different labels for the same concept. Sex Roles, 5, 613-625.

LoRD, R. G., Phillips, J. S., \& Rush, M. C. (1980). Effects of sex and personality on perceptions of emergent leadership influence and social power. Journal of Applied Psychology, 65, 176-182.

MarTin, C. R., JR. (1972). Support for women's lib: Management performance. Southern Journal of Business, 7, 19-28.

PARKer, W. S., JR. (1976). Black-white differences in leader behavior related to subordinates' reactions. Journal of Applied Psychology, 61, 140-147.

RichaRDS, S. A., \& JAFFEE, C. L. (1972). Blacks supervising whites: A study of interracial difficulties in working together in a simulated organization. Journal of Applied Psychology, 56, 234-240.

RUHE, J. A. (1973). The effects of varying racial compositions upon attitudes and behaviors of supervisors and subordinates in simulated work groups. Dissertation Abstracts International, 34, 450B-451B. (University Microfilms No. 73-15, 538)

SashKIN, M., \& GARLAND, H. (1979). Laboratory and field research on leadership: Integrating divergent streams. In J. G. Hunt \& L. L. Larson (Eds.), Crosscurrents in leadership (pp. 64-87). Carbondale, IL: Southern Illinois University Press.

Stitt, C., Schmidt, S., Price, K., \& KiPNis, D. (1983). Sex of leader, leader behavior and subordinate satisfaction. Sex Roles, 9, 31-42.

Terborg, J. R. (1977). Women in management: A research review. Journal of Applied Psychology, 62, 647-664.

Weed, S. E., Mitchell, T. R., \& MoffitT, W. (1976). Leadership style, subordinate personality and task type as predictors of performance and satisfaction with supervisor. Journal of Applied Psychology, 61, 53-66.

WeXley, K. N., \& Hunt, P. J. (1974). Male and female leaders: Comparison of performance and behavior patterns. Psychological Reports, $35,867-872$.

(Manuscript received for publication November 30, 1984.) 